Ophthalmologica 1987;195:I-IV

\title{
Contents, Vol. 195, 1987
}

\section{Contents Vol. 195,1987}

No. 1 Original Paper $\cdot$ Travaux originaux $\cdot$ Originalarbeiten

Long-Term Complications of Toxic Epidermal Necrolysis (LyelГs Disease). Clinical and

Histopathologic Study

Felice, G.P. de; Caroli, R.; Autelitano, A 1

Scanning Electron Microscopic Study of an Anterior Chamber Intraocular Lens: Latent

Endophthalmitis

Schémann, J.F 7

An Epithelioma of the Ciliary Body

Takagi, T.; Tsuda, N.; Watanabe, F.; Takaku, 113

Traitement des uvéites sévères par la ciclosporine $\mathrm{A}$

Harada, T.; Sugita, K.; Saito, A.; Awaya, S 21

Retroequatorial Red Retinal Lesions in Sickle Cell Anemia (With 1 color plate)

Roy, M.S.; Rodgers, G.P.; Noguchi, C.T.; Schechter, A.N 26

Retinal Manifestations of Mediterranean Spotted Fever

Alió, J.; Ruiz-Beltran, R.; Herrero-Herrero, J.I.; Hernandez, E.; Guinaldo, V.; Millan, A. 31

Cytological and Immunological Study of the Aqueous Humor in Acute Retinal Necrosis

Syndrome

Matsuo, T.; Nakayama, T.; Koyama, T.; Matsuo, N 38

Effect of Resection of Lateral Rectus Muscle in Undercorrected Esotropia

Biedner, B.; Yassur, Y 45

Okulo-oto-vertebro-digitales Syndrom. Fallbericht (Mit 1 Farbtafel)

Daxecker, F.; Mayer, W 49

Book Reviews Livres nouveaux Buchbesprechungen

Announcement Communication Ankündigung 56

No. 2 Original Paper · Travaux originaux · Originalarbeiten

HIV Antibody Screening of Corneal Donors

Wilhelmus, K.R.; Farge, E.J 57

Intensität und Dauer der Tränenfilmaufrisszeitänderungen durch handelsiibliche Betablocker und ihre Kombination mit Tränenfilmersatzmitteln

Strempel, $1 \quad 61$

Lens Opacity Meter: A New Instrument to Quantify Lens Opacity

Flammer, J.; Bebie, H 69

Retinal Venous-Venous Anastomoses and Capillary Aneurysms in Juvenile Glaucoma

Okubo, K.; Numura, K.; Nakamura, M 73

Microscope Ocular Fundus Photography (With 1 color plate)

Schirmer, K.E.; Jacques, L.Y 81

Laser Treatment of Macular Subretinal Neovascularizations in Angioid Streaks

Brancato, R.; Menchini, U.; Pece, A.; Davi, G.; Capoferri, C 
Spatial Summation and the Cortical Magnification of Perimetric Profiles

Wild, J.M.; Wood, J.M.; Flanagan, J.G 88

Contents III

Multifocal Pigment Epithelial Damages with Serous Retinal Detachment in SystemicLupus

Erythematosus (With 1 color plate)Matsuo, T.; Nakayama, T.; Koyama, T.; Matsuo, N 97

Clinicopathologic Case Report · Description clinico-pathologique de cas · Klinisch-

pathologische Fallbeschreibung

Orbitale Lipogranulome

Strempel, $1 \quad 104$

Book Reviews Livres nouveaux Buchbesprechungen 109

No. 3 Clinicopathologic Case Report - Description clinicopathologique de cas ·

Klinisch-pathologische Fallbeschreibung

Spontane Hornhautruptur nach Strontiumbestrahlung eines Plattenepithelkarzinoms

derKonjunktiva (Mit 1 Farbtafel)Philipp, W.; Daxecker, F.; Langmayr, J.; Göttinger, W 113

Original Paper · Travaux originaux · Originalarbeiten

A New Hypothesis on Tear Film Stability

Liotet, S.; Van Bijsterveld, O.P.; Kogbe, O.; Laroche, L 119

Analyse eines Dakryolithen

Daxecker, F.; Philipp, W.; Müller-Holzner, E.; Tessadri, R 125

High-Energy Electrons Used to Inhibit Experimental Intraocular Proliferation and Detachment

Binder, S.; Skorpik, Ch.; Paroussis, P.; Kulnig, W.; Menapace, R.; Prokesch, E. ... 128 Trilateral

Malignant Lymphoma: Primary Malignant B-Cell Lymphoma of the Eyes and

Brain. Diagnosis by Transvitreal Retinochoroidal Biopsy

Scherfig, E.; Bauer, B.; Bengtsson-Stigmar, E.; Jensen, O.A.; Johnsson, A.; Prause, J.U. 135

Malaria tropica mit Makulablutung

Jean, B.; Seilnacht, J.; Thiel, H.-J 141

Classification of Diabetic Retinopathy

Haut, J.; Redor, J.Y.; Abboud, E.; van Effenterre, G.; Moulin, F 145

Cerebral Metabolism in Chronic Ocular Ischemia (With 1 color plate)

Yamaguchi, K.; Kiyosawa, M.; Ito, M.; Tamai, M 156

Ocular Complications in Strabismus fixus convergens

Mansour, A.M.; Wang, F.; El-Baba, F.; Henkind, P 161

Book Reviews Livres nouveaux Buchbesprechungen 167

No. 4 Original Paper · Travaux originaux · Originalarbeiten

Granular Dystrophy of the Cornea (Groenouw's Type I). Is the Keratocyte the Primary

Source after All?

Wittebol-Post, D.; van der Want, J.J.L.; van Bijsterveld, O.P

The Corneal Endothelium in Xeroderma pigmentosum

Okubo, K.; Nakamura, M.; Nomura, K.; Kawakami, J.; Ichihashi, M 178

Cavernous Hemangioma of the Iris

Prost, M 183

IV

Contents

Retinal Microaneurysms in a Patient with Drug-Induced Aplastic Anemia

Furuse, N.; Hayasaka, S.; Yamamoto, Y.; Setogawa, T 188

A New Thread Tear Test using Silicone Tubing (With 1 color plate) 
Kurihashi, K 192

Contrast Sensitivity in Multiple Sclerosis. A Study in 35 Patients with and without OpticNeuritisNordmann, J.-P.; Saraux, H.; Roullet, E 199

Pattern-Reversal Electroretinograms from Normotensive, Hypertensive and

GlaucomatousEyesWanger, P.; Persson, H.E205

Inter- and Intraindividual Sensitivity Variations with Manual and Automated Static

PerimetersSues, F.E.; Verriest, G 209

Book Reviews Livres nouveaux Buchbesprechungen 215

Author Index 218

Subject Index 219

S. Karger · Medical and Scientific Publishers

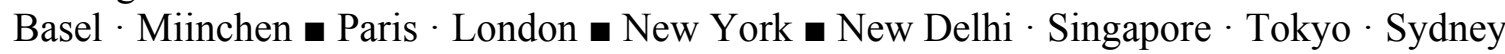

Drug Dosage All rights reserved.

The authors and the publisher have exerted every effort No part of this publication may be translated into otherto ensure that drug selection and dosage set forth in this languages, reproduced or utilized in any form or by anytext are in accord with current recommendations and means, electronic or mechanical, including photocopy-practice at the time of publication.

However, in view of ing, recording, microcopying, or by any information stor-ongoing research, changes in government regulations, age and retrieval system, without permission in writingand the constant flow of information relating to drug from the publisher or, in the case of photocopying, directtherapy and drug reactions, the reader is urged to check payment of a specified fee to the Copyright Clearancethe package insert for each drug for any change in indica- Center (see 'Information for Readers and Subscribers').tions and dosage and for added warnings and precautions. This is particularly important when the recom- C Copyright 1987 by mended agent is a new and/or infrequently employed S. Karger AG, P.O. Box, CH-4009

Basel (Switzerland)

drug. . Printed in Switzerland by

Buchdruckerei Friedrich Reinhardt AG

Basel 